\title{
Synthesis of lipophilic 1-deoxygalactonojirimycin derivatives as D-galactosidase inhibitors
}

\author{
Georg Schitter ${ }^{1}$, Elisabeth Scheucher ${ }^{1}$, Andreas J. Steiner ${ }^{1}$, \\ Arnold E. Stütz ${ }^{1}$, Martin Thonhofer ${ }^{1}$, Chris A. Tarling ${ }^{2}$, Stephen G. Withers ${ }^{2}$, \\ Jacqueline Wicki ${ }^{2}$, Katrin Fantur ${ }^{3}$, Eduard Paschke ${ }^{3}$, Don J. Mahuran ${ }^{4}$, \\ Brigitte A. Rigat ${ }^{4}$, Michael Tropak ${ }^{4}$ and Tanja M. Wrodnigg ${ }^{* 1}$
}

\section{Full Research Paper}

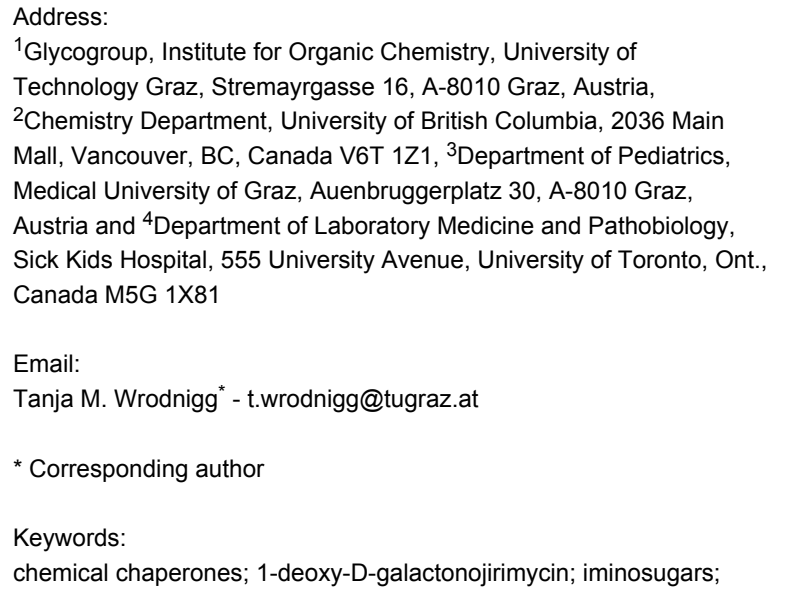

${ }^{1}$ Glycogroup, Institute for Organic Chemistry, University of Technology Graz, Stremayrgasse 16, A-8010 Graz, Austria, ${ }^{2}$ Chemistry Department, University of British Columbia, 2036 Main Mall, Vancouver, BC, Canada V6T 1Z1, ${ }^{3}$ Department of Pediatrics, Medical University of Graz, Auenbruggerplatz 30, A-8010 Graz, Austria and ${ }^{4}$ Department of Laboratory Medicine and Pathobiology, Sick Kids Hospital, 555 University Avenue, University of Toronto, Ont., Canada M5G 1X81

Email:

Tanja M. Wrodnigg* - t.wrodnigg@tugraz.at

* Corresponding author

Keywords:

chemical chaperones; 1-deoxy-D-galactonojirimycin; iminosugars;

lipophilic galactosidase inhibitor; $\mathrm{N}$-modified iminosugars

Beilstein Journal of Organic Chemistry 2010, 6, No. 21 doi:10.3762/bjoc.6.21

Received: 03 December 2009

Accepted: 11 February 2010

Published: 01 March 2010

Guest Editor: T. K. Lindhorst

(c) 2010 Schitter et al; licensee Beilstein-Institut.

License and terms: see end of document.

\begin{abstract}
$N$-Alkylation at the ring nitrogen of the D-galactosidase inhibitor 1-deoxygalactonojirimycin with a functionalised $\mathrm{C}_{6}$ alkyl chain followed by modification with different aromatic substituents provided lipophilic 1-deoxygalactonojirimycin derivatives which exhibit inhibitory properties against $\beta$-glycosidases from E. coli and Agrobacterium sp. as well as green coffee bean $\alpha$-galactosidase. In preliminary studies, these compounds also showed potential as chemical chaperones for GM1-gangliosidosis related $\beta$-galactosidase mutants.
\end{abstract}

\section{Introduction}

Iminosugars such as compounds 1-4 (Figure 1) have been shown to be potent glycosidase inhibitors and useful tools for the study of glycoside-hydrolysing enzymes. These sugar mimetics have been found to have anti-viral, anti-cancer, anti- diabetes, anti-infective, as well as insect anti-feedant and plant growth regulatory effects. Because of their diverse properties, iminosugars have enjoyed continuous interest since their discovery in the $1960 \mathrm{~s}$. Consequently, many different 
<smiles>OC[C@H]1NC[C@@H](O)[C@H](O)[C@@H]1O</smiles>

1<smiles>OC[C@H]1N[C@H](CO)[C@@H](O)[C@@H]1O</smiles>

2<smiles>OC[C@H]1[C@@H](O)[C@H](O)[C@@H]2[C@@H](O)CCN12</smiles>

3<smiles>OC[C@H]1NC[C@@H](O)[C@H](O)[C@@H]1O</smiles>

4

Figure 1: Typical representatives of iminosugars.

derivatives have been prepared for biological evaluations via a wide range of synthetic approaches and have been used for various medicinal and biomolecular applications [1-9].

Recently, iminosugars were found to have potential to serve as pharmacological chaperones for the treatment of lysosomal storage diseases in chaperone mediated therapy (CMT) [10]. In contrast to enzyme replacement therapy (ERT), where recombinant enzyme is given to the patient at regular intervals, the iminosugars used for CMT (recently called pharmacological chaperone therapy, PCT) are able to cross the blood brain barrier. This gives the opportunity also to treat types of lysosomal storage diseases involving the central nervous system. Furthermore, CMT is a cost-efficient alternative to ERT. In this context, $\mathrm{N}$-alkylated derivatives of 1-deoxynojirimycin [11] such as $\mathbf{5}$ and $\mathbf{6}$ (Figure 2) as well as $N$-substituted D-glucono- $\delta$ lactams 7 (Figure 2) [12] have been shown to be highly potent pharmacological chaperones for the potential treatment of Gaucher [13] and Pompe [14] diseases by 'rescuing' the related mutant enzymes. Both Wong [15] and Overkleeft [16] have shown that a rather large lipophilic substituent such as the adamantyl group (8, Figure 2) attached via an alkyl chain with a chain length from $\mathrm{C}_{3}$ up to $\mathrm{C}_{9}$ to the ring nitrogen of 1-deoxynojirimycin and isofagomine respectively, can increase the interaction with the lysosomal glycosphingolipid glucocerebrosidase. Interestingly, 5- $N, 6-X-\left(N^{\prime}\right.$-alkyliminomethylene)nojirimycin derivatives where $\mathrm{X}$ is $\mathrm{O}, \mathrm{NH}$ or $\mathrm{S}$ such as in structure 9 (Figure 2) also have chaperone activity for Gaucher related mutations [17].
1-Deoxygalactonojirimycin (4) was shown to be a candidate for the treatment of Fabry disease, an X-linked inherited lysosomal storage disorder caused by the deficiency of $\alpha$-galactosidase A activity resulting in the accumulation of globotriaosylceramide, thereby affecting the lysosomes of vascular endothelial cells. Iminosugar $\mathbf{4}$ can increase $\alpha$-galactosidase A levels 1.5 to 28 fold in cultured Fabry patient cell lines (baseline $\alpha$-Gal A levels range from $0-52 \%$ ) after incubation for five days, as was observed for 49 different missense mutant forms [18-21]. It can also reduce tissue globotriaosylceramide levels in a mouse model [22].

Suzuki and co-workers found, that $N$-octyl-4-epi- $\beta$-valienamine (10) (Figure 3), a competitive inhibitor of lysosomal $\beta$-galactosidase, when orally administered to GM1-gangliosidosis model mice, is able to enter the brain through the bloodbrain barrier and thereby enhancing $\beta$-galactosidase activity, reduce substrate storage, and clinically improve neurological deterioration [23].

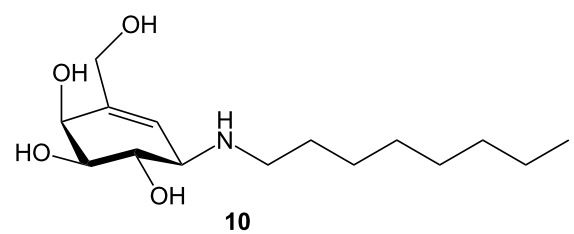

Figure 3: Structure of NOEV 10.<smiles>[R]N1C[C@H](O)[C@@H](O)[C@H](O)[C@H]1CO</smiles>

5: $\mathrm{R}=\mathrm{C}_{4} \mathrm{H}_{9}$ 6: $\mathrm{R}=\mathrm{C}_{9} \mathrm{H}_{19}$<smiles>[R]N1C[C@H](O)[C@H](O)[C@H](O)C1=O</smiles>

7: $\mathrm{R}=\mathrm{C}_{8} \mathrm{H}_{17}$ $\mathrm{Bn},\left[\mathrm{CH}_{2}\right]_{6} \mathrm{OH}$<smiles>[Y]CC1CC2CC1CC(C)(CN1CC([R])C(O)C(O)C1CO)C2</smiles>

8a: Overkleeft: $\mathrm{R}=\mathrm{OH}, \mathrm{X}=\mathrm{O}, n=1$

8b: Wong: $\mathrm{R}=\mathrm{H}, \mathrm{X}=\mathrm{CONH}, n=0$<smiles>[X]C1=NCCC2[C@H](O)[C@@H](O)[C@@H](O)[C@H](O)N12</smiles>

9: $\mathrm{X}=\mathrm{O}, \mathrm{S}, \mathrm{NH}$

Figure 2: N-Modified iminosugars 5-9 as potential pharmacological chaperones. 


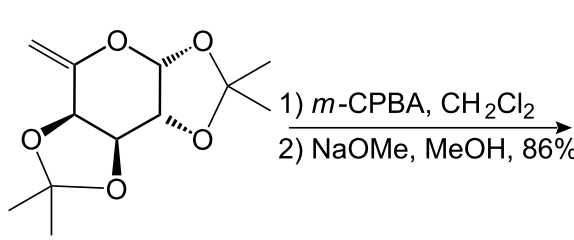

10<smiles>CC1(C)O[C@@H]2[C@H](O1)[C@@](O)(CO)O[C@@H](O)[C@@H]2O</smiles>

$\stackrel{\mathrm{BnNH}_{2}, \mathrm{MeOH}, \mathrm{Pd} / \mathrm{C}}{\longrightarrow}$<smiles>CC1(C)O[C@H]2[C@@H](CO)NC[C@@H](O)[C@H]2O1</smiles>

12

Scheme 1: Three-step-synthesis of partially protected 1-deoxy-D-galactonojirimycin derivative 12 from 10 via L-arabino-hexos-5-ulose 11.

Our studies revealed that 1-deoxy-D-galactonojirimycin-lysine hybrids, when carrying an aromatic substituent, such as a dansyl moiety, in its nature a lipophilic aromatic substituent, are potent D-galactosidase inhibitors and also show activity with human lysosomal $\beta$-galactosidase, exhibiting improvements of the enzyme activity in mutant cell lines [24]. In the course of this work, we became interested in the influence of other lipophilic aromatic substituents on the biological activity of such compounds. Different aromatic acid derivatives were prepared by coupling to the free amine at the terminus of the $\mathrm{C}_{6}$ alkyl chain in compound 15, which is anchored to the ring nitrogen of 1-deoxygalactonojirimycin, to yield derivatives 16-19 and 22. The spacer length of six carbon units has been proven suitable for enzyme recognition in previous studies [25] and was kept constant to compare the different aromatic substituents. Additionally, Wong [15] as well as Suzuki [23] have shown from computational studies, that in case of $N$-substitution on compounds $\mathbf{8 b}$ and 10, the iminosugar and carbasugar units respectively, were found to interact with the active site of the corresponding enzymes whereas the alkyl chains were located in the distinctly hydrophobic entrance region to the active site. Thus, for comparison, a lipophilic aliphatic tert-butyl group in compound $\mathbf{2 0}$ was included in this study. In addition to the synthetic approaches, the influence of the lipophilic substituents of the new $\mathrm{N}$-modified 1-galactonojirimycin derivatives on their biological interaction with respective glycoside hydrolases are described.

\section{Results and Discussion}

The key intermediate for the synthesis of $N$-modified lipophilic 1-deoxygalactonojirimycin derivatives $\mathbf{1 6 - 2 0}$ as well as $\mathbf{2 2}$ was the 3,4-O-isopropylidene iminosugar 12. Starting from enol ether 10 [26,27], treatment with $m$-chloroperbenzoic acid gave the 5-O-chlorobenzoic ester via the corresponding 5,6-epoxide. This ester underwent hydrolysis under basic conditions to afford the L-arabino-hexos-5-ulose 11, which was immediately used for the next step after brief silica gel purification. The reductive amination and $\mathrm{N}$-deprotection of $\mathbf{1 1}$ was carried out under an atmosphere of $\mathrm{H}_{2}$ with benzylamine in methanol and $\mathrm{Pd} / \mathrm{C}$ as catalyst to produce 3,4-O-isopropylidene-1-deoxy-D-galactonojirimycin (12) in an overall yield of $75 \%$ (Scheme 1).

Compound 12 underwent $\mathrm{N}$-substitution upon treatment with 1-O-tosyl-6- $N$-(tert-butoxycarbonyl)-6-aminohexanol (13) [28] in DMF to give the 1-deoxygalactonojirimycin derivative $\mathbf{1 4}$ in $64 \%$ yield. The isopropylidene and tert-butoxycarbonyl protecting groups were simultaneously removed under standard conditions to afford the desired free amine 15 [25], the key building block for further modifications (Scheme 2).

The chemoselective acylation of the free amine $\mathbf{1 5}$ was conducted with three different benzoic acid derivatives in order to investigate the influence of the potential basicity of an additional nitrogen at the aromatic substituent. For the synthesis of compound 16, 4-isopropylbenzoic acid was reacted with the primary amine under amide coupling conditions with $O$-(benzotriazol-1-yl)- $N, N, N^{\prime}, N^{\prime}$-tetramethyluronium tetrafluoro-borate (TBTU) as the coupling reagent in DMF and triethylamine. Likewise, nicotinic acid under the same conditions gave compound $\mathbf{1 7}$ in $20 \%$ yield. Reaction of $\mathbf{1 5}$ with 4-(dimethylamino)benzoyl chloride in DMF and triethylamine afforded derivative 18 in 22\% yield (Scheme 3 ). These unusu-<smiles>[Y20][C@H]1OC(C)(C)O[C@@H]1[C@H](O)CO</smiles><smiles>CC(C)(C)CCCCNCCCCCOC(C)(C)C</smiles><smiles>CCCCN1C[C@H](O)[C@@H]2OC(C)(C)O[C@@H]2[C@H]1CO</smiles>

14

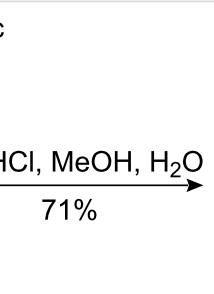<smiles>NCN1C[C@H](O)[C@@H](O)[C@H](O)[C@@H]1CO</smiles>

15

Scheme 2: Synthesis of $N$-(6-aminohexyl)-1-deoxygalactonojirimycin (15) from 12 via 14. 


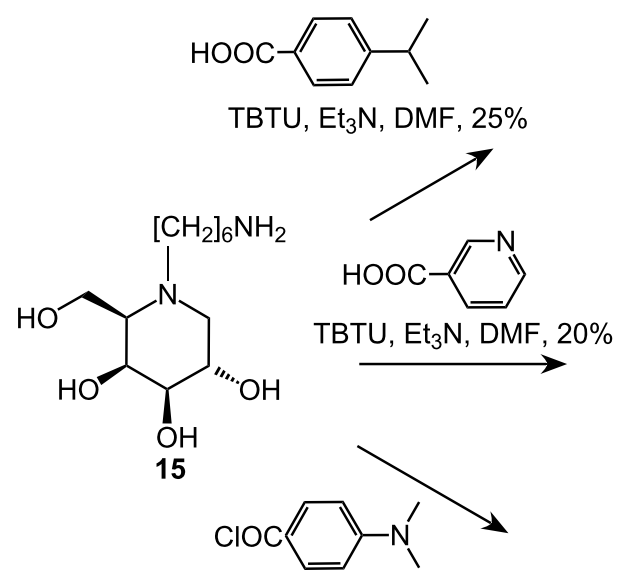

$\mathrm{Et}_{3} \mathrm{~N}, \mathrm{DMF}, 22 \%$<smiles>C/C=C\CCCCCNC(=O)c1ccc(C(C)C)cc1</smiles><smiles>CN(C)c1ccc(C(=O)NCCCCCCN2C[C@H](O)[C@@H](O)[C@H](O)[C@H]2CO)cc1</smiles>

Scheme 3: Synthesis of lipophilic 1-deoxy-D-galactonojirimycin derivatives 16-18 by chemoselective acylation of 15 .

ally low yields for the standard coupling reactions were due to the formation of very polar side products as well as material losses during column chromatography.

For increased lipophilicity as well as for analytical purposes, compound 15 was also coupled to 1-pyrenebutyric acid with TBTU in DMF in the presence of triethylamine to give compound 19 in $56 \%$ yield. The pyrenyl substituent was chosen because of its potential to serve as diagnostic tool. Conventional BOC-protection of amine $\mathbf{1 5}$ gave derivative $\mathbf{2 0}$ in $81 \%$ yield (Scheme 4).

Aromatic derivative 22 was synthesised from 4 [29-42] (conveniently obtained by deprotection of compound $\mathbf{1 2}$ under acidic conditions), in $77 \%$ yield by ring nitrogen alkylation with tosylate 21 (Scheme 5) [43].

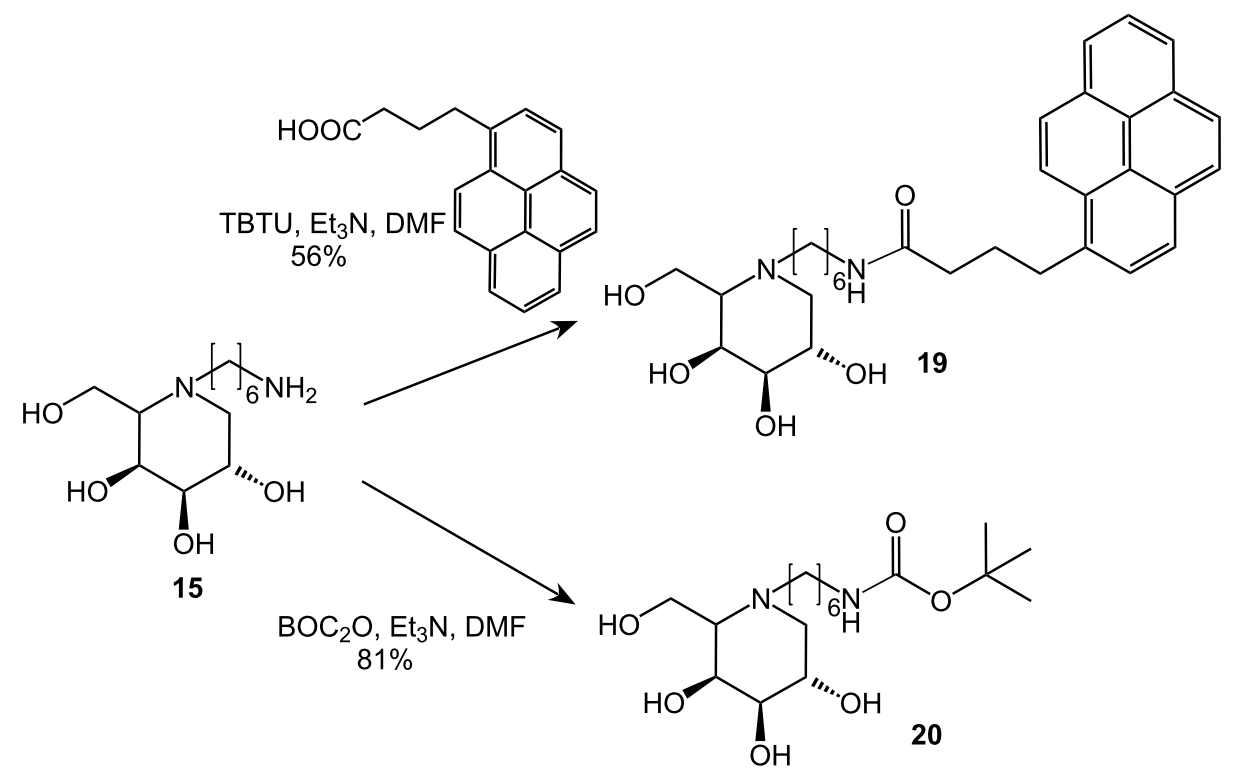




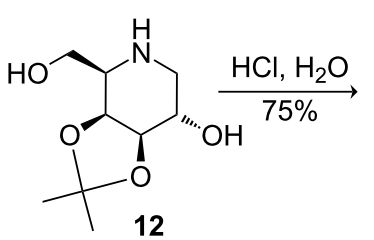<smiles>OCC1NCC(O)C(O)C1O</smiles>
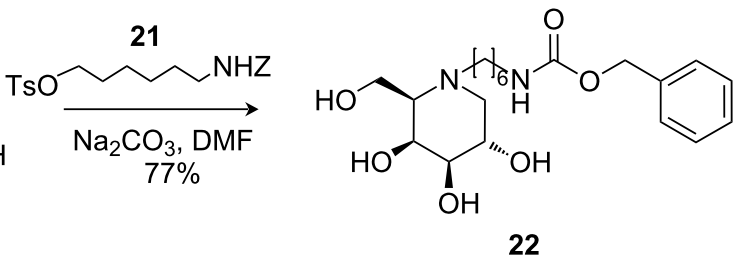

22

Scheme 5: Synthesis of compound 22

Inhibition constants of the compounds synthesised are presented in Table 1. The 1-deoxygalactonojirimycin analogues were tested as inhibitors of Agrobacterium sp. $\beta$-glucosidase/ galactosidase and $E$. coli $\beta$-galactosidase as well as green coffee bean $\alpha$-galactosidase (Table 1). All new compounds inhibited the Agrobacterium sp. enzyme better than the parent iminosugar 4. The pyrenyl substituted compound 19 with an extended aromatic system turned out to be the most active inhibitor with a $K_{\mathrm{i}}$ value of $60 \mathrm{nM}$ against Agrobacterium sp. $\beta$-glucosidase/ galactosidase and $0.25 \mu \mathrm{M}$ against $E$. coli $\beta$-galactosidase. However, the toxicity of this compound clearly requires further evaluation. In general, $N$-substitution does not dramatically affect the inhibitory properties of the derivatives against $\beta$-galactosidase from $E$. coli, with $K_{\mathrm{i}}$ values distributed in the range of the parent iminosugar 4 . No particular trend could be observed in a comparison of compounds $\mathbf{1 6}-\mathbf{1 9}$ as regards the presence or absence of the additional nitrogen at the aromatic substituent. Iminosugars $\mathbf{1 6 - 2 0}$, as well as $\mathbf{2 2}$, were less active than the parent compound with $\alpha$-galactosidase from green coffee beans. However, the $K_{\mathrm{i}}$ values are still in the low $\mu \mathrm{M}$ range and thus, suitable for use as chemical chaperones. Gratifyingly, compounds $\mathbf{2 0}$ and $\mathbf{2 2}$ exhibited $\mathrm{IC}_{50}$ values of

Table 1: Inhibitory activities of compounds $16-20$ and 22 with $\beta$-glycosidases from Agrobacterium sp. ( $\beta$-glu/gal Abg), E. coli ( $\beta$-gal E. coli) as well as with the $\alpha$-galactosidase from green coffee beans ( $\alpha$-gal $\mathrm{GCB}$ ).

\begin{tabular}{llll} 
Compound & $\begin{array}{l}K_{\mathrm{i}}[\mu \mathrm{M}] \\
\beta \text {-glu/gal Abg }\end{array}$ & $\begin{array}{l}K_{\mathrm{i}}[\mu \mathrm{M}] \\
\beta \text {-gal E. coli }\end{array}$ & $\begin{array}{l}K_{\mathrm{i}}[\mu \mathrm{M}] \\
\alpha-\text {-gal GCB }\end{array}$ \\
\hline $\mathbf{4}$ & 100 & 13 & $0.013^{\mathrm{a}}$ \\
$\mathbf{1 6}$ & 13 & 1.3 & 2.6 \\
$\mathbf{1 7}$ & 1.5 & 0.83 & 2.2 \\
$\mathbf{1 8}$ & 3.8 & 1.1 & 0.49 \\
$\mathbf{1 9}$ & 0.06 & 0.25 & 7.0 \\
$\mathbf{2 0}$ & 3.0 & 2.4 & 4.3 \\
$\mathbf{2 2}$ & 6.0 & 0.4 & 2.2 \\
\hline
\end{tabular}

asee reference [7].
$10.9 \mu \mathrm{M}\left(K_{\mathrm{i}}=2.0 \mu \mathrm{M}\right)$ and $3.26 \mu \mathrm{M}\left(K_{\mathrm{i}}=0.72 \mu \mathrm{M}\right)$, respectively, with human lysosomal $\beta$-galactosidase.

In preliminary studies compounds $\mathbf{1 7}$ as well as $\mathbf{2 2}$ served as chemical chaperone and increased the enzyme activity of a $\beta$-galactosidase mutant feline fibroblast cell line up to 5.5 fold when applied at a concentration of $100 \mu \mathrm{M}$. Compound 18 was a significantly better chemical chaperone for this mutant increasing the relative enzyme activity 4.8 fold at a concentration of $2 \mu \mathrm{M}$.

\section{Conclusion}

We have synthesised new 1-deoxygalactonojirimycin derivatives 16-20, as well as $\mathbf{2 2}$, which feature a $\mathrm{C}_{6}$ chain anchored to the ring nitrogen. Different lipophilic aromatic and aliphatic substituents at the $N$-alkyl chain were introduced resulting in an interesting $K_{\mathrm{i}}$-value profile against $\beta$-galactosidases from $\mathrm{Abg}$ and $E$. coli, respectively, as well as with $\alpha$-galactosidase from green coffee beans. The $K_{\mathrm{i}}$ values with human lysosomal $\beta$-galactosidase and preliminary data for chaperone activity in a cat fibroblast model of the new compounds suggest that such iminosugar derivatives have interesting potential in the chaperone-mediated therapy of lysosomal storage diseases, such as, for example, GM1 gangliosidosis as well as Morquio B disease, possibly also Fabry's disease. Further bio-medicinal evaluation and toxicity studies are currently in progress.

\section{Supporting Information}

\section{Supporting Information File 1}

Full experimental details and characterisation data [http://www.beilstein-journals.org/bjoc/content/ supplementary/1860-5397-6-21-S1.pdf]

\section{Acknowledgements}

G. S. thanks the Institute of Organic Chemistry for financial support (January-June 2009). 


\section{References}

1. Winchester, B. G. Tetrahedron: Asymmetry 2009, 20, 645-651. doi:10.1016/j.tetasy.2009.02.048

2. Compain, P.; Martin, O. Iminosugars: From Synthesis to Therapeutic Applications; Wiley-VCH: Weinheim, 2008.

3. Martin, O. R.; Compain, P. Curr. Top. Med. Chem. 2003, 3, 541-560. doi:10.2174/1568026033452474

4. Asano, N.; Nash, R. J.; Molyneux, R. J.; Fleet, G. W. J. Tetrahedron: Asymmetry 2000, 11, 1645-1680. doi:10.1016/S0957-4166(00)00113-0

5. Wrodnigg, T. M. From Lianas to glycobiology tools: Twenty-five years of 2,5-dideoxy-2,5-imino-D-mannitol. In Timely Research Perspectives in Carbohydrate Chemistry; Schmid, W.; Stütz, A. E., Eds.; Springer: Vienna, AUT., 2002; pp 393-426.

6. Heightman, T. D.; Vasella, A. T. Angew. Chem., Int. Ed. 1999, 38, 750-770

doi:10.1002/(SICI)1521-3773(19990315)38:6<750::AID-ANIE750>3.0. CO;2-6

7. Stütz, A. E. Iminosugars as Glycosidase Inhibitors; Wiley-VCH: Weinheim, 1999.

8. Bols, M. Acc. Chem. Res. 1998, 31, 1-8. doi:10.1021/ar970058r

9. Legler, G. Adv. Carbohydr. Chem. Biochem. 1990, 48, 319-384. doi:10.1016/S0065-2318(08)60034-7

10. Parenti, G. EMBO Mol. Med. 2009, 1, 268-278. doi:10.1002/emmm.200900036

11. Yu, L.; Ikeda, K.; Kato, A.; Adachi, I.; Godin, G.; Compain, P.; Martin, O.; Asano, N. Bioorg. Med. Chem. 2006, 14, 7736-7744. doi:10.1016/j.bmc.2006.08.003

12. Wang, G. N.; Reinkensmeier, G.; Zhang, S.-W.; Zhou, J.; Zhang, L. R.; Zhang, L.-H.; Butters, T. D.; Ye, X. S. J. Med. Chem. 2009, 52, 3146-3149. doi:10.1021/jm801506m

13. Sanchez-Olle, G.; Duque, J.; Egido-Gabas, M.; Casa, J.; Lluch, M.; Chabas, A.; Grinberg, D.; Vilageliu, L. Blood Cells, Mol., Dis. 2009, 42, 159-166. doi:10.1016/j.bcmd.2008.11.002

14. Porto, C.; Cardone, M.; Fontana, F.; Rossi, F.; Tuzzi, M. R.; Tarallo, A.; Barone, M. V.; Andria, G.; Parenti, G. Mol. Ther. 2009, 17, 964-971. doi:10.1038/mt.2009.53

15. Yu, Z.; Sawkar, A. R.; Whalen, L. J.; Wong, C.-H.; Kelly, J. W. J. Med. Chem. 2007, 50, 94-100. doi:10.1021/jm060677i

16. Wennekes, T.; van den Berg, R. J. B. H. N.; Donker, W.; van der Marel, G. A.; Strijland, A.; Aerts, J. M. F. G.; Overkleeft, H. S. J. Org. Chem. 2007, 72, 1088-1097. doi:10.1021/jo061280p

17. Luan, Z.; Higaki, K.; Aguilar-Moncayo, M.; Ninomiya, H.; Ohno, K.; García-Moreno, M. I.; Ortiz Mellet, C.; García Fernandez, J. M.; Suzuki, Y. ChemBioChem 2009, 10, 2780-2792. doi:10.1002/cbic. 200900442

18. Fan, J. Q.; Ishii, S. FEBS J. 2007, 274, 4962-4971. doi:10.1111/j.1742-4658.2007.06041.x

19. Hamanaka, R.; Shinohara, T.; Yano, S.; Nakamura, M.; Yasuda, A.; Yokoyama, S.; Fan, J. Q.; Kawasaki, K.; Watanabe, M.; Ishii, S. Biochim. Biophys. Acta 2008, 1782, 408-413.

20. Benjamin, E. R.; Flanagan, J. J.; Schilling, A.; Chang, H. H.; Agarwal, L.; Katz, E.; Wu, X.; Pine, C.; Wustman, B.; Desnick, R. J.; Lockhart, D. J.; Valenzano, K. J. J. Inherited Metab. Dis. 2009, 32, 424-440. doi:10.1007/s10545-009-1077-0

21. Park, J. Y.; Kim, G. H.; Kim, S. S.; Ko, J. M.; Lee, J. J.; Yoo, H. W. Exp. Mol. Med. 2009, 41, 1-7. doi:10.3858/emm.2009.41.1.001
22. Khanna, R.; Soska, R.; Lun, Y.; Feng, J.; Frascella, M.; Young, B.; Brignol, N.; Pellegrina, L.; Sitaraman, S. A.; Desnick, R. J.; Benjamin, E. R.; Lockhart, D. J.; Valenzyno, K. J. Mol. Ther. 2010, 18, 23-33. doi:10.1038/mt.2009.220

23. Suzuki, Y.; Ogawa, S.; Sakakibara, Y. Perspect. Med. Chem. 2009, 3, 7-17.

24. Steiner, A. J.; Schitter, G.; Stütz, A. E.; Wrodnigg, T. M.; Tarling, C. A.; Withers, S. G.; Fantur, K.; Mahuran, D.; Paschke, E.; Tropak, M. Bioorg. Med. Chem. 2008, 16, 10216-10220. doi:10.1016/j.bmc.2008.10.054

25. Greimel, P.; Häusler, H.; Lundt, I.; Rupitz, K.; Stütz, A. E.; Tarling, C. A.; Withers, S. G.; Wrodnigg, T. M. Bioorg. Med. Chem. Lett. 2006, 16, 2067-2070. doi:10.1016/j.bmcl.2006.01.095

26. Garegg, P. J.; Samuelsson, B. J. Chem. Soc., Perkin Trans. 1 1980, 2866-2869. doi:10.1039/P19800002866

27. Helferich, B.; Himmen, E. Ber. Dtsch. Chem. Ges. B 1929, 62, 2139-2141. doi:10.1002/cber.19290620842

28. Hansen, J. B.; Buchardt, O. J. Chem. Soc., Chem. Commun. 1983, 4, 162-164. doi:10.1039/C39830000162

29. Wennekes, T.; Lang, B.; Leeman, M.; van der Marel, G. A.; Smits, E.; Weber, M.; van Wiltenburg, J.; Wolberg, M.; Aerts, J. M. F. G.; Ovekleeft, H. S. Org. Process Res. Dev. 2008, 12, 414-423. doi:10.1021/op700295x

30. Takahata, H.; Banda, Y.; Ouchi, H.; Nemoto, H. Org. Lett. 2003, 5, 2527-2529. doi:10.1021/ol034886y

31. Shilvock, J. P.; Nash, R. J.; Watson, A. A.; Winters, A. L.; Butters, T. D.; Dwek, R. A.; Winkler, D. A.; Fleet, G. W. J. J. Chem. Soc., Perkin Trans. 1 1999, 2747-2754. doi:10.1039/a904145a

32. Asano, K.; Hakogi, T.; Iwama, S.; Katsumura, S. Chem. Commun. 1999, 41-42. doi:10.1039/a807532h

33. Barili, P. L.; Berti, G.; Catelani, G.; D’Andrea, F.; de Rensis, F.; Puccioni, L. Tetrahedron 1997, 53, 3407-3416. doi:10.1016/S0040-4020(97)00063-X

34. Johnson, C. R.; Golebiowski, A.; Sundram, H.; Miller, M. W.; Dwaihy, R. L. Tetrahedron Lett. 1995, 36, 653-654. doi:10.1016/0040-4039(94)02343-A

35. Chida, N.; Tanikawa, T.; Tobe, T.; Ogawa, S. J. Chem. Soc., Chem. Commun. 1994, 1247-1248. doi:10.1039/C39940001247

36. Furneaux, R.; Tyler, P. C.; Whitehouse, L. A. Tetrahedron Lett. 1993, 34, 3609-3612. doi:10.1016/S0040-4039(00)73649-5

37. Lees, W. J.; Whitsides, G. M. Bioorg. Chem. 1992, 20, 173-179. doi:10.1016/0045-2068(92)90037-4

38. Liu, K. K. C.; Kajimoto, T.; Chen, L.; Zhong, Z.; Ichikawa, Y.; Wong, C. H. J. Org. Chem. 1991, 56, 6280-6289. doi:10.1021/jo00022a013

39. Aoyagi, S.; Fujimaki, S.; Yamazaki, N.; Kibayashi, C. J. Org. Chem. 1991, 56, 815-819. doi:10.1021/j000002a057

40. Heiker, F. R.; Schueller, A. M. Carbohydr. Res. 1990, 203, 314-318. doi:10.1016/0008-6215(90)80031-W

41. Bernotas, R. C.; Pezzone, M. A.; Ganem, B. Carbohydr. Res. 1987, 167, 305-311. doi:10.1016/0008-6215(87)80289-6

42. Legler, G.; Pohl, S. Carbohydr. Res. 1986, 155, 119-129. doi:10.1016/S0008-6215(00)90138-1

43. Krivickas, S. J.; Tamanini, E.; Todd, M. H.; Watkinson, M. J. Org. Chem. 2007, 72, 8280-8289. doi:10.1021/jo071175v 


\section{License and Terms}

This is an Open Access article under the terms of the Creative Commons Attribution License

(http://creativecommons.org/licenses/by/2.0), which permits unrestricted use, distribution, and reproduction in any medium, provided the original work is properly cited.

The license is subject to the Beilstein Journal of Organic Chemistry terms and conditions:

(http://www.beilstein-journals.org/bjoc)

The definitive version of this article is the electronic one which can be found at:

doi:10.3762/bjoc. 6.21 